Historic, Archive Document

Do not assume content reflects current scientific knowledge, policies, or practices. 


1968 Reserve
A $9 \% .9$
U. S. Forest Service
Research Paper RM-36

$F 76324$

Silvicultural Control of Dwarf Mistletoe

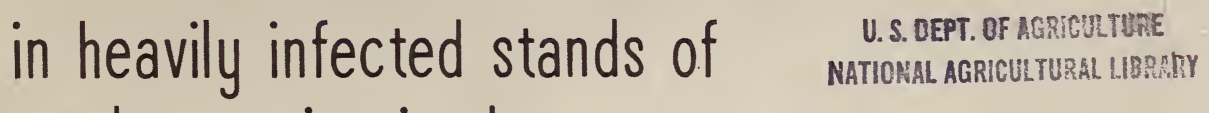
ponderosa pine in the

Southwest

AUG 211968

CURRENT SERIAL RECORDS

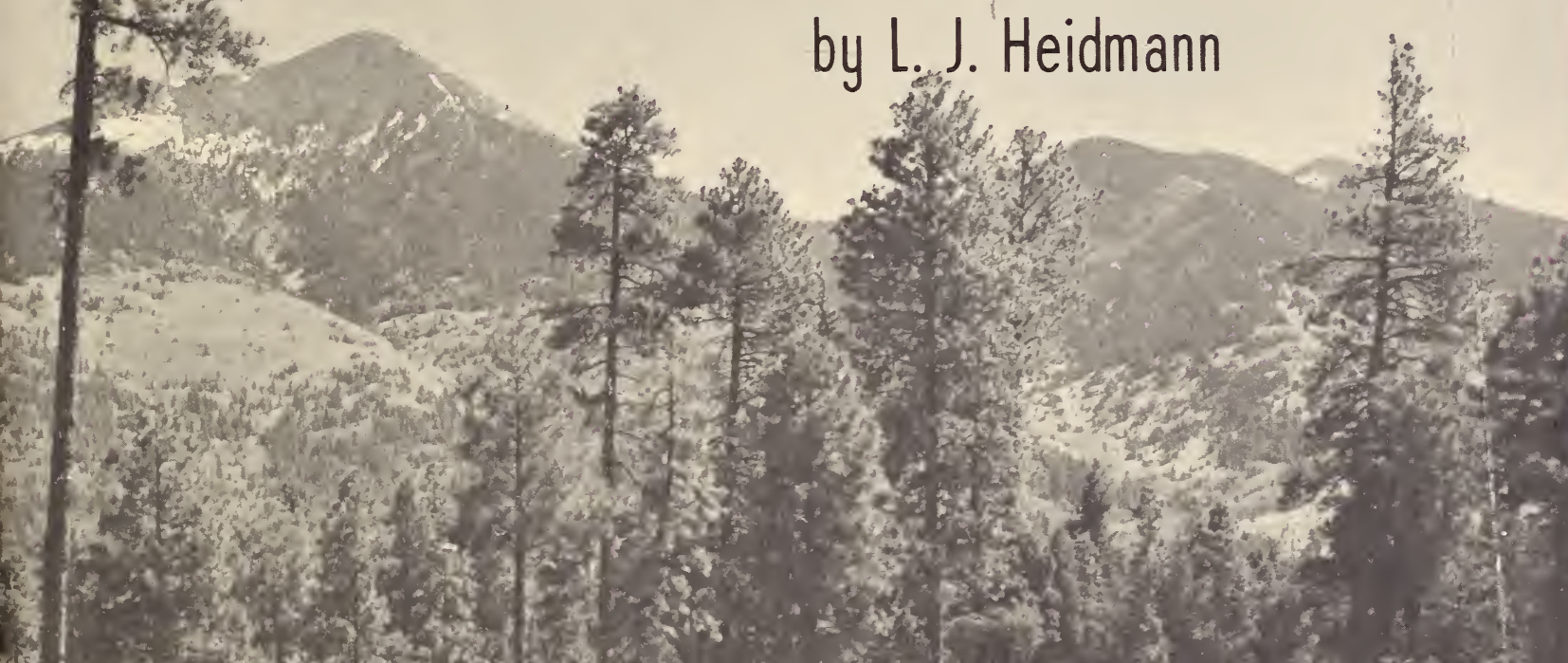

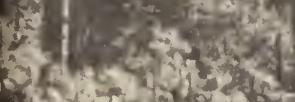

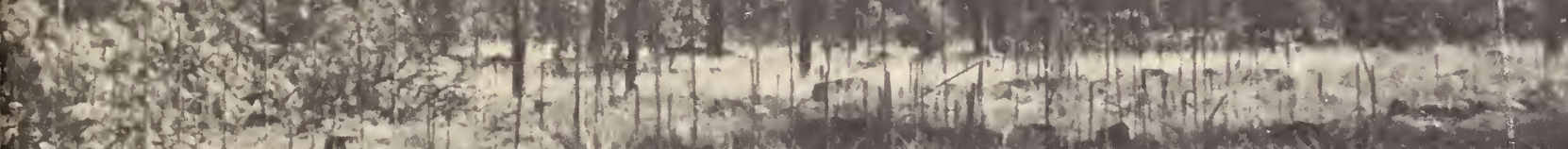

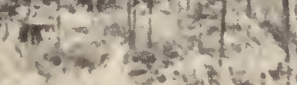

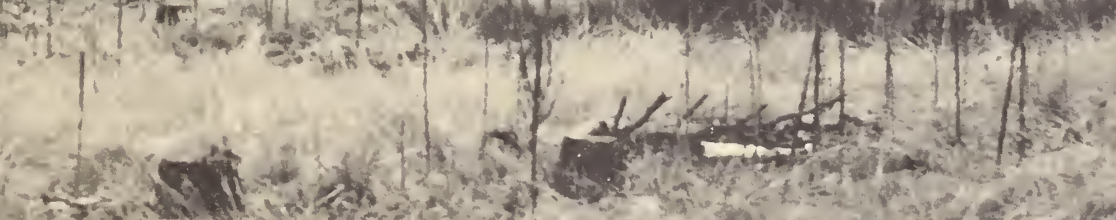

$$
\text { cets } f(x
$$

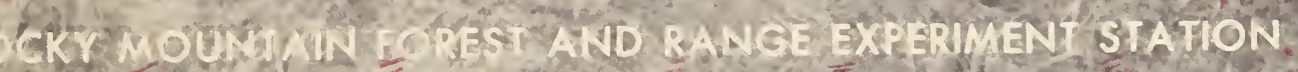


Silvicultural Control of Dwarf Mistletoe in Heavily Infected Stands

of Ponderosa Pine in the Southwest

by

L. J. Heidmann, Associate Silvicuiturist

Rocky Mountain Forest and Range Experiment Station ${ }^{1}$

${ }^{1}$ Central headquarters maintained in cooperation with Colorado State University at Fort Collins; author is located at Flagstaff in cooperation with Northern Arizona University. 
CONTENTS

Page

The study .

Treatments

Limited dwarf mistletoe control

Complete dwarf mistletoe control Light improvement selection cutting.

Effect of treatment on stocking

Volume status on treated areas.

Reforestation

Costs and returns

Discussion

Summary and conclusions

Literature cited
1

2

2

4

5

6

8

10

10

10

11

11 


\title{
Silvicultural Control of Dwarf Mistletoe \\ in Heavily Infected Stands of \\ Ponderosa Pine in the Southwest
}

\author{
L. J. Heidmann
}

Dwarf mistletoe (Arceuthobium vaginatum f. cryptopodum (Engelm.) Gill) is the most destructive disease of ponderosa pine (Pinus ponderosa Laws.) in the Southwest (Hawksworth 1961). Andrews and Daniels (1960) estimated that this parasite causes an annual mortality of 55 to 75 million board feet of ponderosa pine in Arizona and New Mexico; about 2.5 million of the 7.5 million acres of commercial ponderosa pine timberland are infected. Heaviest infections are found in the virgin stands, usually with diseased groups irregularly intermixed with healthy groups.

The greatest spread of dwarf mistletoe is from overstory to understory trees (Gill and Hawksworth 1954). Therefore, uneven-aged stands are infected more rapidly and severely than even-aged stands. Fortunately, many forests in the Southwest are two-aged by groups of varying acreages. Fully stocked mature and overmature groups generally do not have an understory of younger trees. Where younger age classes occur as an understory, the overstory trees usually do not fully occupy the site.

Silvicultural treatments to reduce or eliminate dwarf mistletoe in the ponderosa pine forests of Arizona have been tested for many years. $^{2}$ This Paper summarizes information collected for 13 years from a large-scale study in northern Arizona (Herman 1961).

\section{The Study}

The study was made in a virgin stand of ponderosa pine that was heavily infected with

${ }^{2}$ Gizl 1954, Gill and Hawksworth 1954, Herman 1961, Korstian and Long 1922. dwarf mistletoe on the Fort Valley Experimental Forest, near Flagstaff, Arizona. The area is on an alluvial fan on the southwest base of the San Francisco Peaks. The soil is a gravelly silt loam. Site index is about 60. Annual precipitation at the Forest headquarters, 2 miles west of the study area, is about 23 inches.

The study was designed to answer four questions:

1. Can dwarf mistletoe in heavily infected stands be controlled through such silvicultural measures as harvest cutting and stand improvement?

2. What is the influence of light improvement selection cutting on dwarf mistletoe?

3. What are the relative costs and returns from practices that stress dwarf mistletoe control?

4. Is dwarf mistletoe control a sound management objective in heavily infected stands?

Each of three treatments was replicated three times on nine 25-acre plots. Each plot included an isolation strip, which raised the total treated area of each plot to approximately 40 acres. The plots were laid out in 1950 , and harvest cuttings to remove the infected sawtimber trees were completed in 1951. In 1953, cultural operations to remove or reduce infection in the smaller trees were carried out. The plots were first re-treated in 1958 and 1959. In 1963 the area was marked for the second re-treatment, but was not cut. To determine posttreatment stocking and infection, marked trees were assumed to have been cut. 
Treatments

\section{Limited Dwarf Mistletoe Control}

The objective of limited control was to reduce the intensity of infection to a level unimportant to timber production. Control measures were restricted to practices that could be financed and accomplished by the U.S. Forest Service under then current allotments and regulations. Thinning and pruning were limited to funds available from $\mathrm{K}-\mathrm{V}$ deposits. ${ }^{3}$ Sustained yield was considered to be of secondary importance until reasonable control of dwarf mistletoe could be achieved.

3 Funds collected for timber stand improvement work under Knutsen-Vandenburg Act of 1930.
The initial harvest cut was designed to remove most of the infected sawtimber (fig. 1), except where removal would leave a large nonstocked opening without an adequate seed source. The guides for leaving infected sawtimber-sized trees needed for stocking or for seed trees were:

1. Leave if all active infections were within 17 feet of the ground and could be pruned out during timber stand improvement after harvest cutting.

2. Leave if infections were in the lower bole or on a single declining branch anywhere in the crown, and if they offered little threat of infection to understory trees.

3. Leave if multiple active infections were confined to the lower one-fourth of the

Figure 1.--Limited control:
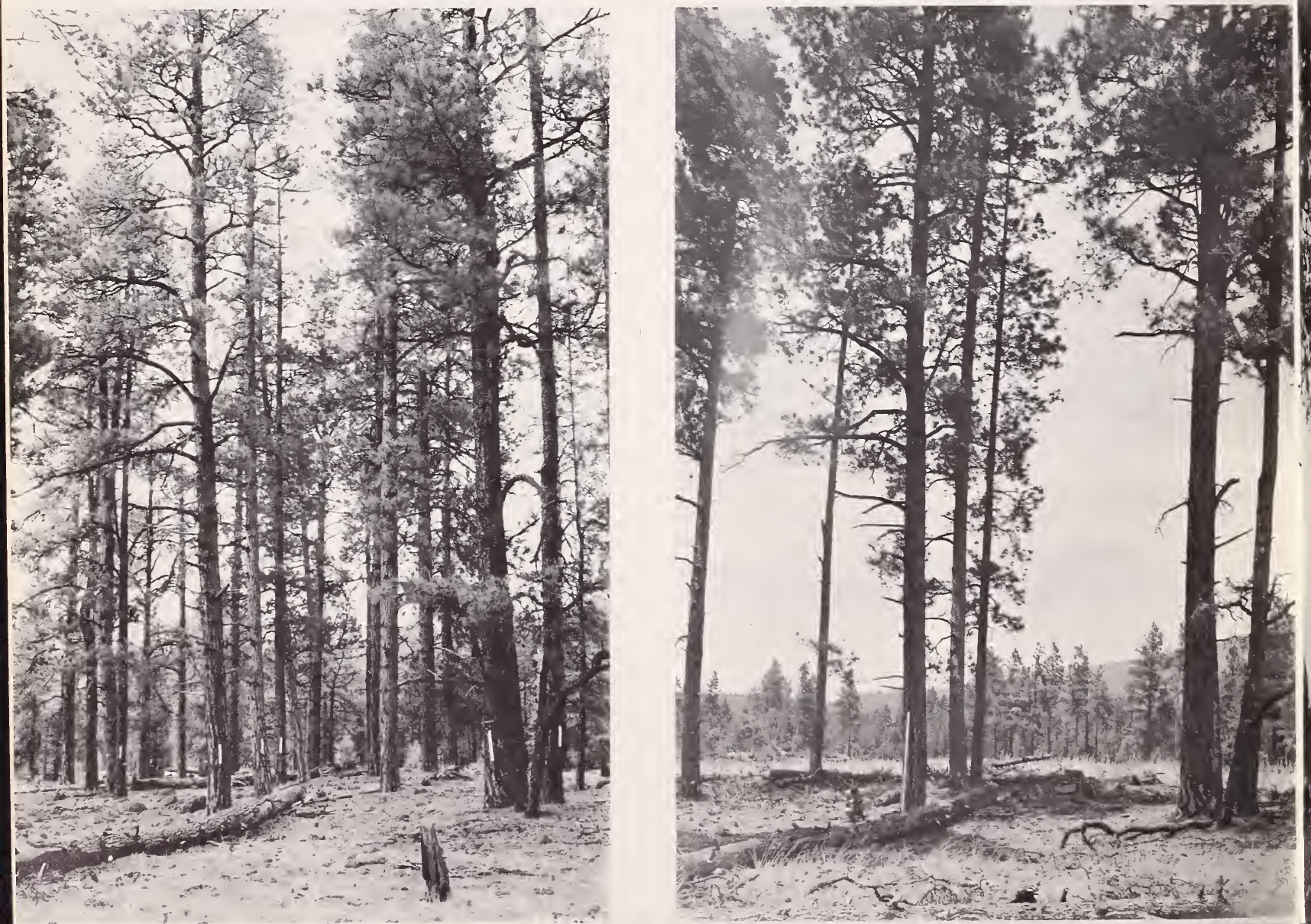
crown, and if there were no smaller noninfected trees within 60 feet of the infected tree.

Guides for timber stand improvement after each harvest cut treatment were:

Group 1.-Non infected: No trees to be cut or pruned.

Group 2.-Occasional infected trees: All infected poles and tall saplings to be cut or poisoned, except where this would reduce stocking below a minimum level. ${ }^{4}$ Where understocking would result, treatment to be as described under group 4 below.

4 Minimum stocking was defined as that resulting in a growing space of $43,560 \div(2 D)^{2}$ where $D$ equals average d.b.h. in inches.

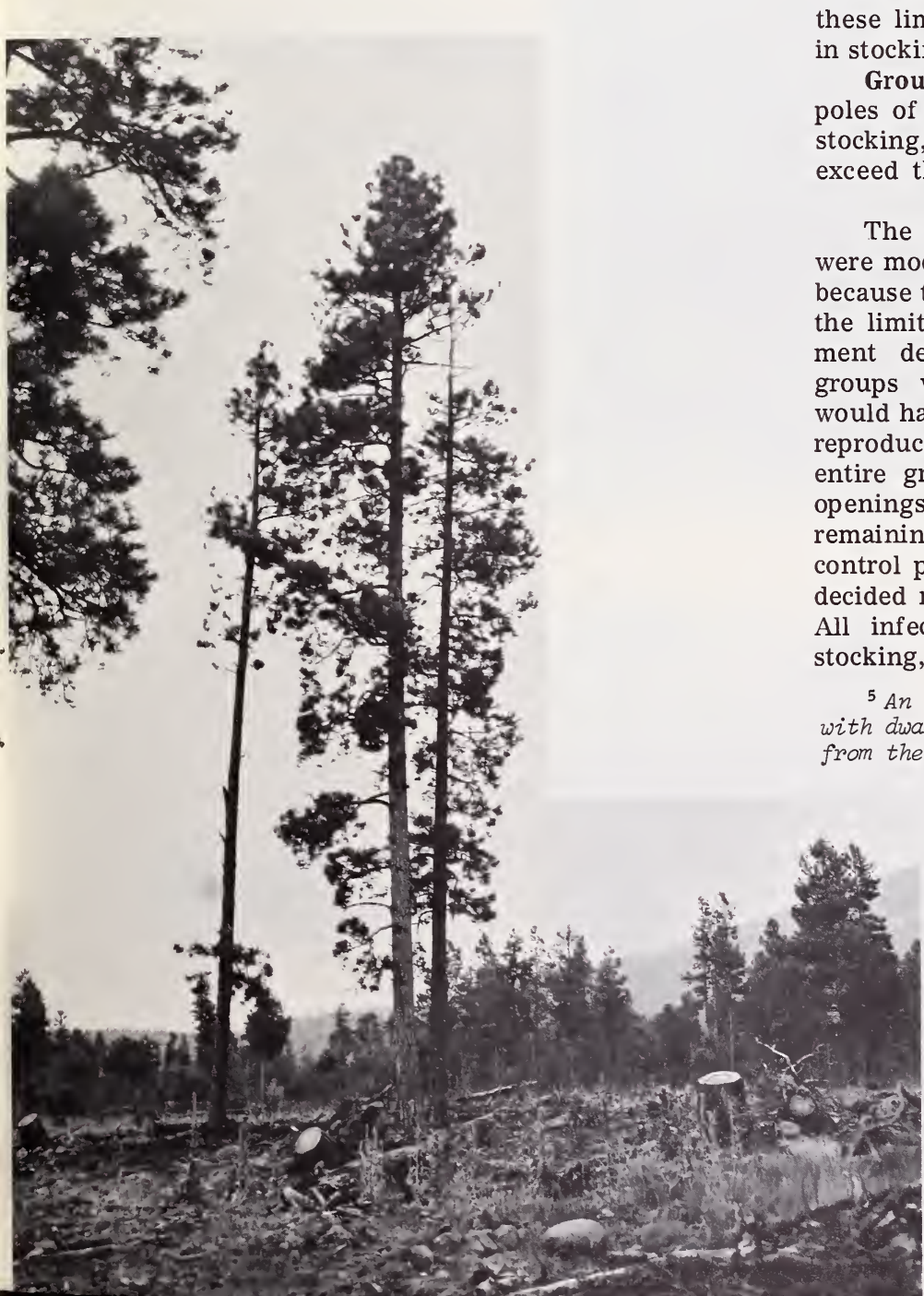
poles or tall saplings to be cut, except where the number of infected trees exceeded 10 percent of the total number in the group. In such cases, the treatment to be as described under group 4 below.

Group 4.-All or nearly all trees infected: Infected poles and saplings of desirable form to be left to provide minimum stocking if the number of noninfected poles is inadequate. Trees with a prunable infection ${ }^{5}$ or bole infection below the crown to be left where available. Otherwise, poles with some nonprunable infections to be left if total infection could be reduced to specified limits by pruning. These limits are (a) not more than two separate infections spaced no farther apart than onethird the live-crown length, or (b) three or more infections, but all in the same one-third of the crown. Trees with infections exceeding these limits to be cut regardless of reduction stocking.

Group 5.-Scattered infected poles: Infected es of desirable form to be left if needed for stocking, and if the degree of infection did not

The treatment procedures described above were modified for the first re-treatment in 1958, because there was very little difference between the limited treatment and the complete treatment described below. All trees in some groups were so severely infected that they uld have jeopardized existing or subsequent eproduction. In such infection centers, the ntire group was cut and large understocked ings were created. Since nearly all trees remaining after the initial treatment on limited control plots were needed for stocking, it was decided not be cut or poison any infected trees. All infected trees were pruned and left for ocking, regardless of residual infection.

An infection within 17 feet of the ground with dwarf mistletoe shoots 12 inches or more rom the bole.
1958--Stumps are from trees that blew down in November 1957. 


\section{Complete Dwarf Mistletoe Control}

The objective of complete control was to reduce infection to as near zero as possible (fig. 2). All noninfected trees were to be saved. Sustained yield was not an immediate objective during the control phase.

All infected trees were included in the treatment. All infected sawtimber-sized trees were harvested. Infected poles, saplings, and seedlings not needed for stocking were cut or poisoned. Trees needed for stocking were pruned if pruning eliminated all visible infections. No trees below sawtimber size with bole infections, branch infections within 12 inches of the bole, or unreachable infections were left, regardless of effect on stocking. Costs of thinning and pruning of infected trees were not limited to available $\mathrm{K}-\mathrm{V}$ deposits.

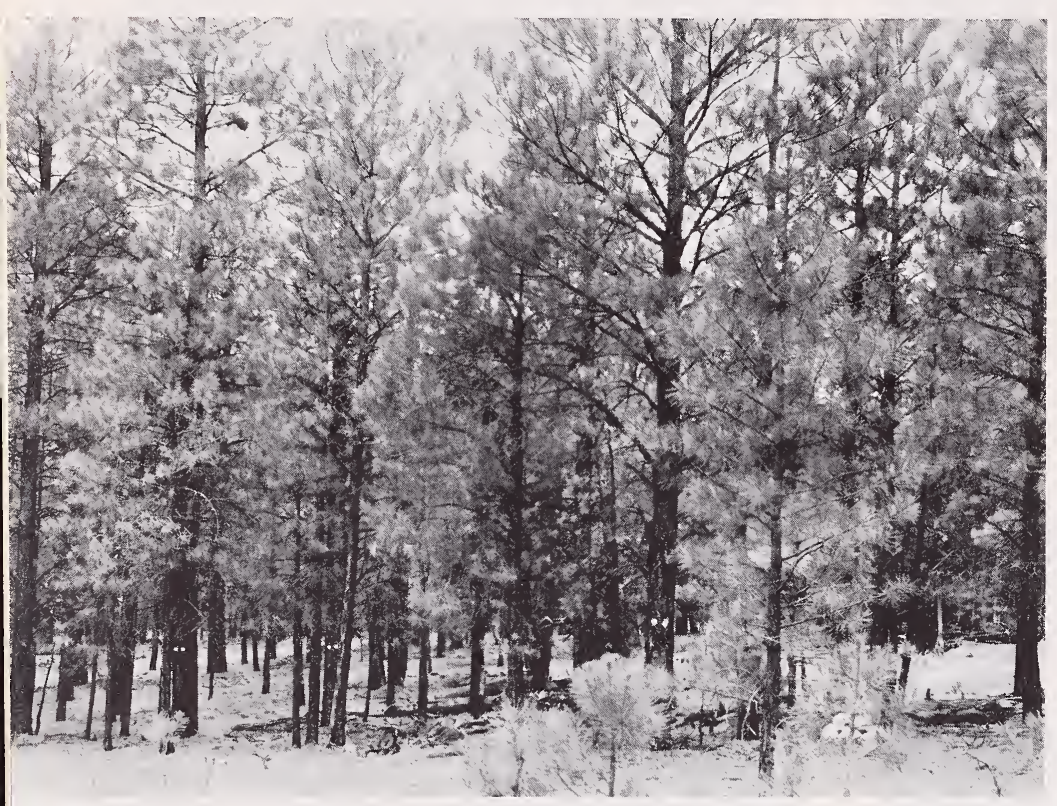

8
Figure 2.--Complete control:

1951--Before treatrient.
1959--After seconä treatment in 1958. AZZ poles in foreground, above, were removed. Such areas need to be reforested. 


\section{Light Improvement Selection Cutting}

The objective of light improvement selection was to provide a standard of current practices for comparative purposes. This system was used by the Forest Service in virgin stands in the Southwest at the time the study was established. With few exceptions, dwarf mistletoe reduction then in practice was limited to sanitation measures that did not reduce stocking or residual volumes below those recommended for noninfected areas (fig. 3).
The primary objective of the first cut in a virgin stand was to reduce mortality losses by harvesting all merchantable trees that were dying or were expected to die during the following cutting cycle. This cut removed 30 to 40 percent of the total board foot volume. Management was directed primarily toward sustained yield of sawtimber on a cutting cycle of 20 years or less.

Stand improvement was limited to that possible from $\mathrm{K}-\mathrm{V}$ collections of the cut sawtimber. Guides for the stand improvement work after the first harvest cut were:
Figure 3.--

Light improvement selection:

1951--Before treatment.

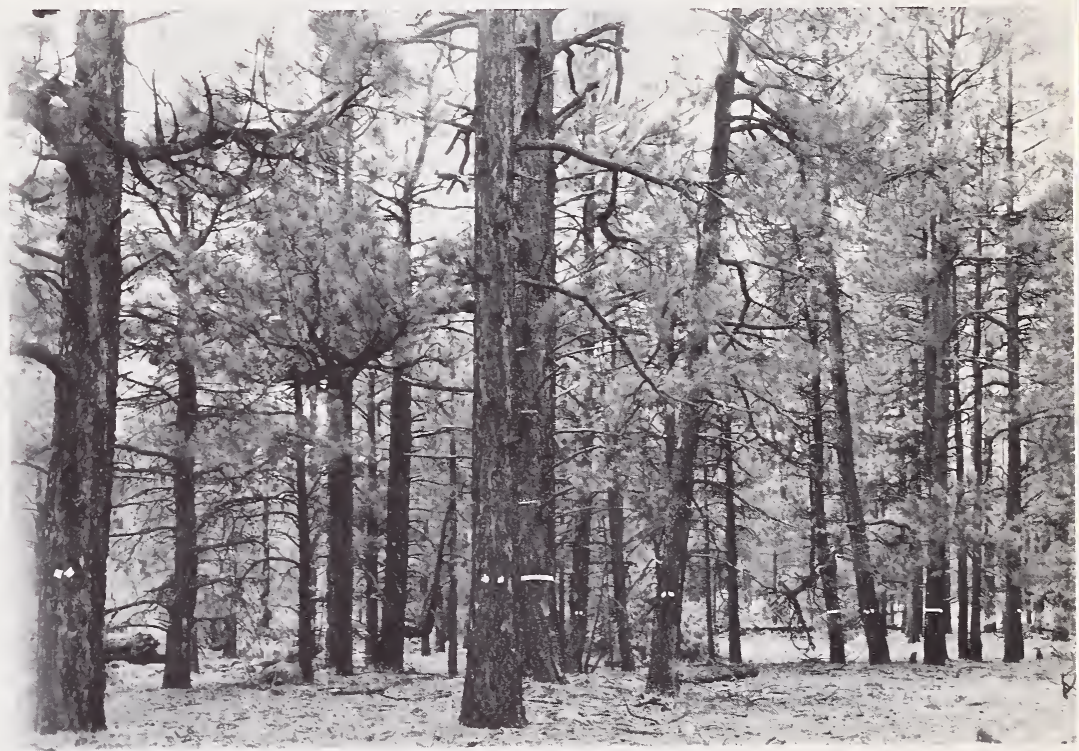

1959--After second treatment in 1958.

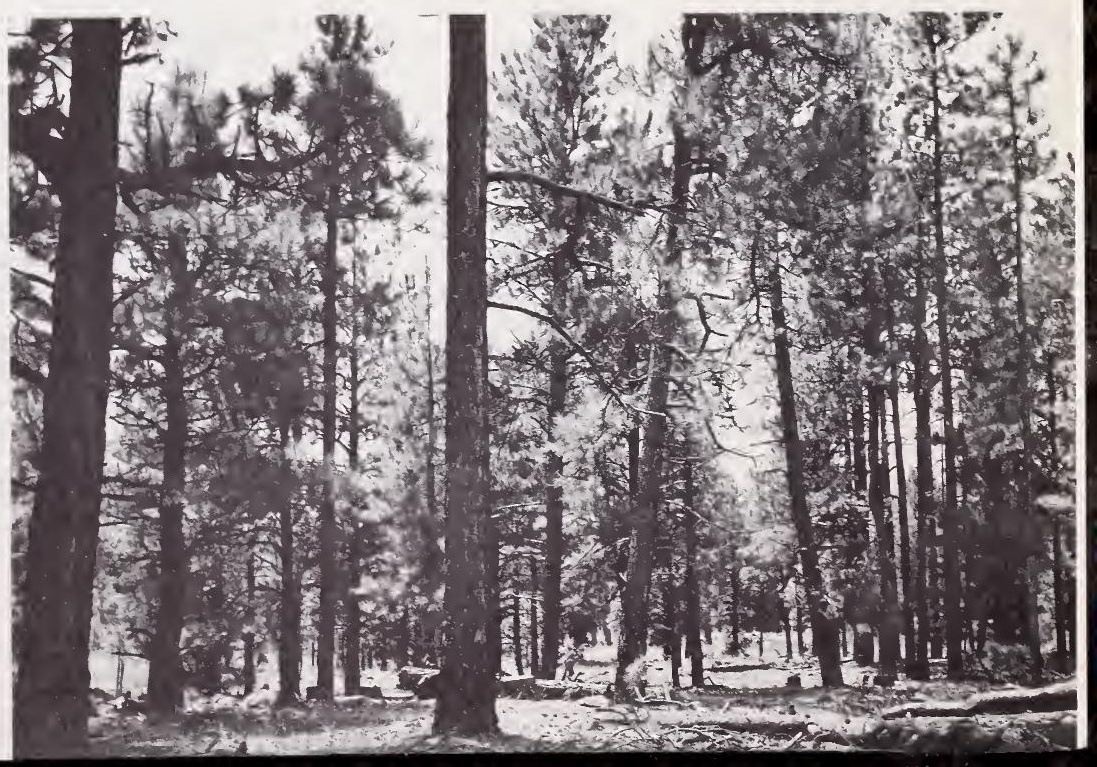


1. Pruning and release of pruned trees were usually restricted to noninfected pole groups at least 50 feet from an infected overstory.

2. Where there were no noninfected groups, pruning and release were limited to lightly infected groups. In such groups, crop trees free of infection were selected where available. Otherwise, trees containing prunable infections were pruned and released.

3. Poles in groups severely infected with dwarf mistletoe or less than 50 feet from an infected overstory were not to be pruned or released. Some pruning was done within 50 feet of infected overstory trees, however, apparently because dwarf mistletoe was overlooked.

Additional harvest cuts are planned at 20year intervals. Only dwarf mistletoe reduction treatments in common use on the southwestern National Forests at the time of each cutting will be used. Stand improvement practices will also be those in effect on the National Forests at the time of cutting.

\section{Effect of Treatment on Stocking}

Degree of stocking was determined by a point stocking system based on the space requirement of the largest tree occupying the point (U. S. Forest Service 1958). Space required by ponderosa pine, in terms of the radius of a circle, was as follows:

\begin{tabular}{|c|c|c|}
\hline & Size range & $\begin{array}{l}\text { Radial space } \\
\text { required } \\
\text { (Feet) }\end{array}$ \\
\hline $\begin{array}{l}\text { Sawtimber: } \\
\text { Large }\end{array}$ & $\begin{array}{r}30 \text { inches d.b.h. or } \\
\text { larger }\end{array}$ & (1. \\
\hline $\begin{array}{l}\text { Medium } \\
\text { Sma11 } \\
\text { Poles: }\end{array}$ & $\begin{array}{l}\text { 20-29 inches d.b.h. } \\
\text { 12-19 inches d.b.h. }\end{array}$ & $\begin{array}{l}26 \\
18\end{array}$ \\
\hline $\begin{array}{l}\text { Large } \\
\text { Sma17 } \\
\text { Saplings } \\
\text { Seedlings }\end{array}$ & $\begin{array}{l}8-11 \text { inches d.b.h. } \\
4-7 \text { inches d.b.h. } \\
1-3 \text { inches d.b.h. } \\
\text { Less than } 4-1 / 2 \text { feet } \\
\text { tall }\end{array}$ & $\begin{array}{r}13 \\
9 \\
6\end{array}$ \\
\hline
\end{tabular}

The percentage of the entire study area stocked with infected and noninfected trees (fig. 4) was: $\frac{\text { Infected }}{--(\text { Noninfected }}$ Total

Limited control:

$\begin{array}{lrll}1950 & 46 & 47 & 93 \\ 1953 & 5 & 51 & 56 \\ 1958 & 16 & 39 & 55 \\ 1963 & 17 & 51 & 68\end{array}$

Complete control:

$\begin{array}{lrrr}1950 & 52 & 40 & 92 \\ 1953 & 3 & 51 & 54 \\ 1958 & 0 & 45 & 45 \\ 1963 & 0 & 51 & 51\end{array}$

Light improvement selection:

$\begin{array}{llll}1950 & 40 & 48 & 88 \\ 1953 & 40 & 40 & 80 \\ 1958 & 37 & 41 & 78 \\ 1963 & 44 & 38 & 82\end{array}$

Total stocking is increasing under all three treatments, with the greatest increase in the sawtimber class (fig. 4).

The limited control treatment reduced total and infected stocking significantly during the 10-year period. The initial harvest cut and followup thinning and pruning in 1953 reduced the stocked area by 37 percent and the infected stocking by 42 percent. After the first treatment, 44 percent of the area was nonstocked, with only 4 percent of it stocked with infected trees. After re-treatment in 1958, total stocking remained about the same as in 1953, but from 1958-63, it increased 13 percent. Infected stocking increased 12 percent the first 5 years, but slowed to a 1 percent increase in the next 5 .

Complete control had the greatest impact on both total and infected stocking. Removal of all visibly infected trees and branches in 1958 markedly reduced total stocking, but was so successful that by 1963 total stocking increased 6 percent even after all newly infected trees and branches were removed again.

Light improvement selection has had very little effect on total or infected stocking during the first 10 years. The initial harvest cut and stand improvement measures reduced the total stocked area by only 8 percent, but did not reduce the area stocked with infected trees. Twenty percent of the area was left unstocked and 40 percent had infected trees. By 1963, both total and infected area stocking had increased slightly -2 and 4 percent, respectively. 
$\checkmark$ Seedlings \& saplings $\quad$ Sawtimber Infected 四 Poles 血 Total $\square$ Noninfected

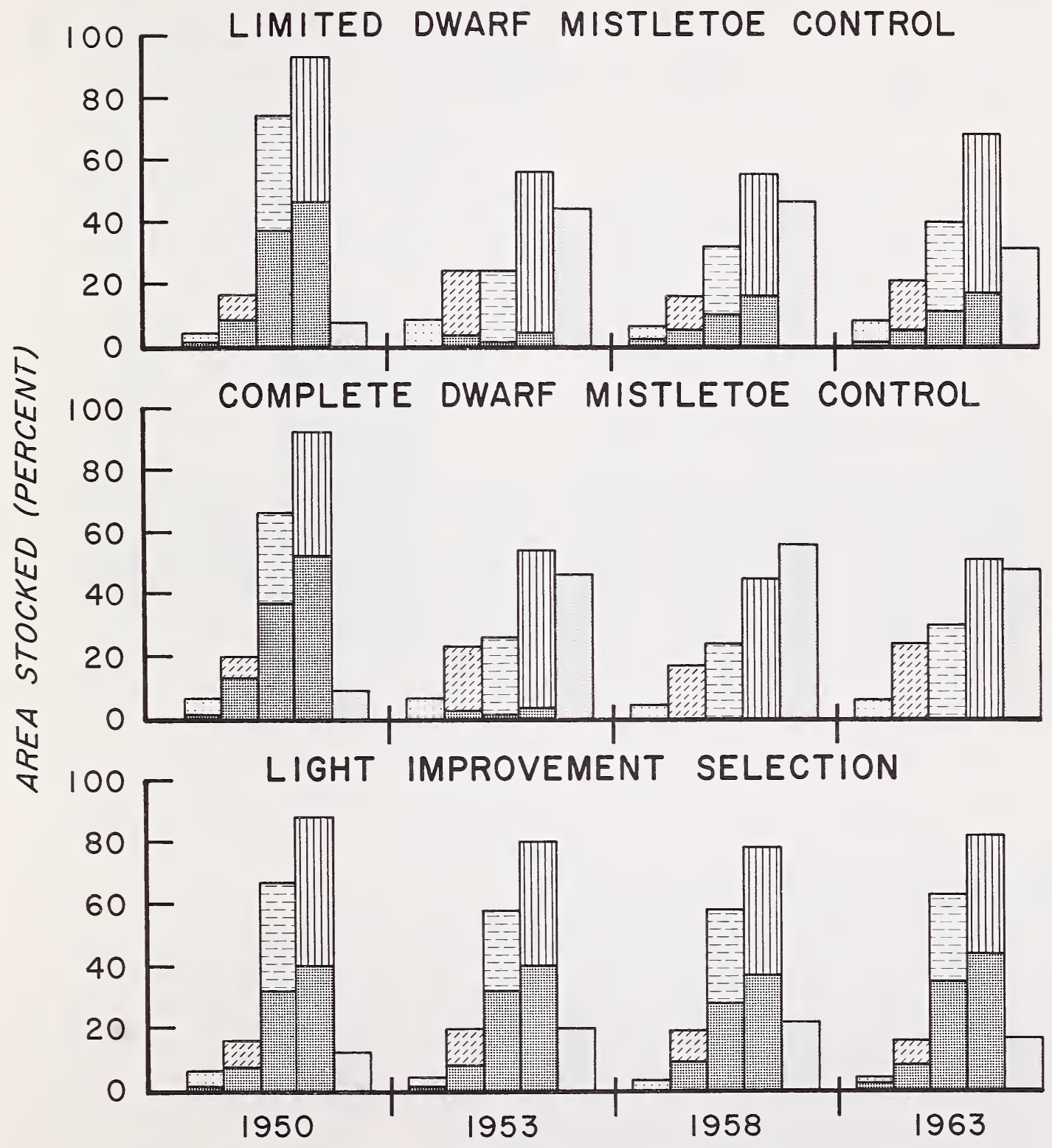

Figure 4.--Effect of three intensities of harvest cutting and stand improvement on infected and total stocking of a stand infected with dwarf mistletoe. 


\section{Volume Status on Treated Areas}

Before treatment, the three plots were similar, with average sawtimber volume of 11,400 board feet per acre (table 1), and similar infected volumes:

\begin{tabular}{lc} 
& Percent \\
\cline { 2 - 2 } & 44 \\
Limited control & 50 \\
Complete control & 40
\end{tabular}

The initial treatments removed the most volume from the limited (LC) and complete control (CC) plots; the least from the light improvement selection (LIS) plots. Under the LC treatment, 78 percent of the sawtimber volume was removed, which eliminated all but 8 percent of the infected volume. Under CC, 75 percent of the volume was cut, with only 1 percent of the infected volume remaining on the plots. The LIS cut, with major emphasis on removal of only dead and dying trees, removed 35 percent of the original volume and reduced infected volume by only 4 percent.

Total volume declined on all plots between 1953 and 1958 (fig. 5, table 1), primarily because of a severe windstorm in November 1957, that removed 250,000 board feet from the study area. Windthrow losses per acre, in relation to volume cut and the reserve stand, were:

$\begin{array}{lrrrr} & \underline{\text { LC }} & \underline{C C} & \underline{\text { LIS }} \\ \text { Percent of volume cut } & 78 & 75 & 35 \\ \text { Number of reserved trees } & 14.8 & 16.4 & 30.7 \\ \text { Number of trees blown down } & 1.5 & 1.4 & .6 \\ \text { Percent of trees blown down } & 10.1 & 8.5 & 1.95\end{array}$

Relative losses of reserve sawtimber-sized trees were highest on LC and CC plots, which had received the heaviest cut in 1951 (fig. 6). In 1958, some infected sawtimber-sized trees were cut on $\mathrm{CC}$, a few culls were removed from LC, and none taken from LIS plots.

The increase in sawtimber volumes on all plots since 1958 (table 1) reflects both growth on trees over 12 inches in diameter, and ingrowth of poles into the sawtimber classes. Volume increase, 1958-63, was:

\begin{tabular}{lc} 
& Percent \\
\cline { 2 - 2 } & \\
Limited control & 22 \\
Complete control & 29 \\
Light improvement selection & 4
\end{tabular}

Infected volume remains highest on LIS; lowest on CC (table 1). After the 10-year period, 43 percent of the residual volume on LIS still has dwarf mistletoe, infected volume continues to increase on LC, but is virtually eliminated on CC plots.

Table 1.--Summary of change in total and dwarf mistletoe-infected sawtimber volume under three silvicultural treatments, 1950-63

\begin{tabular}{|c|c|c|c|c|c|c|c|c|c|}
\hline \multirow{2}{*}{$\begin{array}{l}\text { Treatment } \\
\text { and period }\end{array}$} & \multicolumn{5}{|c|}{ Total volume } & \multicolumn{4}{|c|}{ Infected volume } \\
\hline & Original & Growth & Total & Cut & $\begin{array}{c}\text { Resid- } \\
\text { ual }\end{array}$ & Original & Increase & Cut & $\begin{array}{c}\text { Resid- } \\
\text { ual }\end{array}$ \\
\hline \multicolumn{10}{|c|}{$\begin{array}{l}\text { Light improvement } \\
\text { selection: }\end{array}$} \\
\hline $1950-51$ & 11,410 & -- & 11,410 & 4,044 & 7,366 & 4,579 & -- & 1,903 & 2,676 \\
\hline $1951-58$ & 7,366 & 405 & 7,771 & 533 & 7,238 & 2,676 & 52 & 0 & 2,728 \\
\hline $1958-63$ & 7,238 & 324 & 7,562 & 0 & 7,562 & 2,728 & 524 & 0 & 3,252 \\
\hline \multicolumn{10}{|l|}{ Limited control: } \\
\hline $1950-51$ & 11,671 & -- & 11,671 & 9,067 & 2,604 & 5,123 & -- & 4,950 & 173 \\
\hline $1951-58$ & 2,604 & 354 & 2,958 & 640 & 2,318 & 173 & 174 & 0 & 347 \\
\hline $1958-63$ & 2,318 & 515 & 2,833 & 0 & 2,833 & 347 & 305 & 0 & 652 \\
\hline \multicolumn{10}{|c|}{ Complete control: } \\
\hline $1950-51$ & 11,161 & -- & 11,161 & 8,361 & 2,800 & 5,635 & -- & 5,623 & 12 \\
\hline $1951-58$ & 2,800 & 18 & 2,818 & 619 & 2,199 & 12 & 0 & 12 & 0 \\
\hline $1958-63$ & 2,199 & 638 & 2,837 & 0 & 2,837 & 0 & 0 & 0 & 0 \\
\hline
\end{tabular}




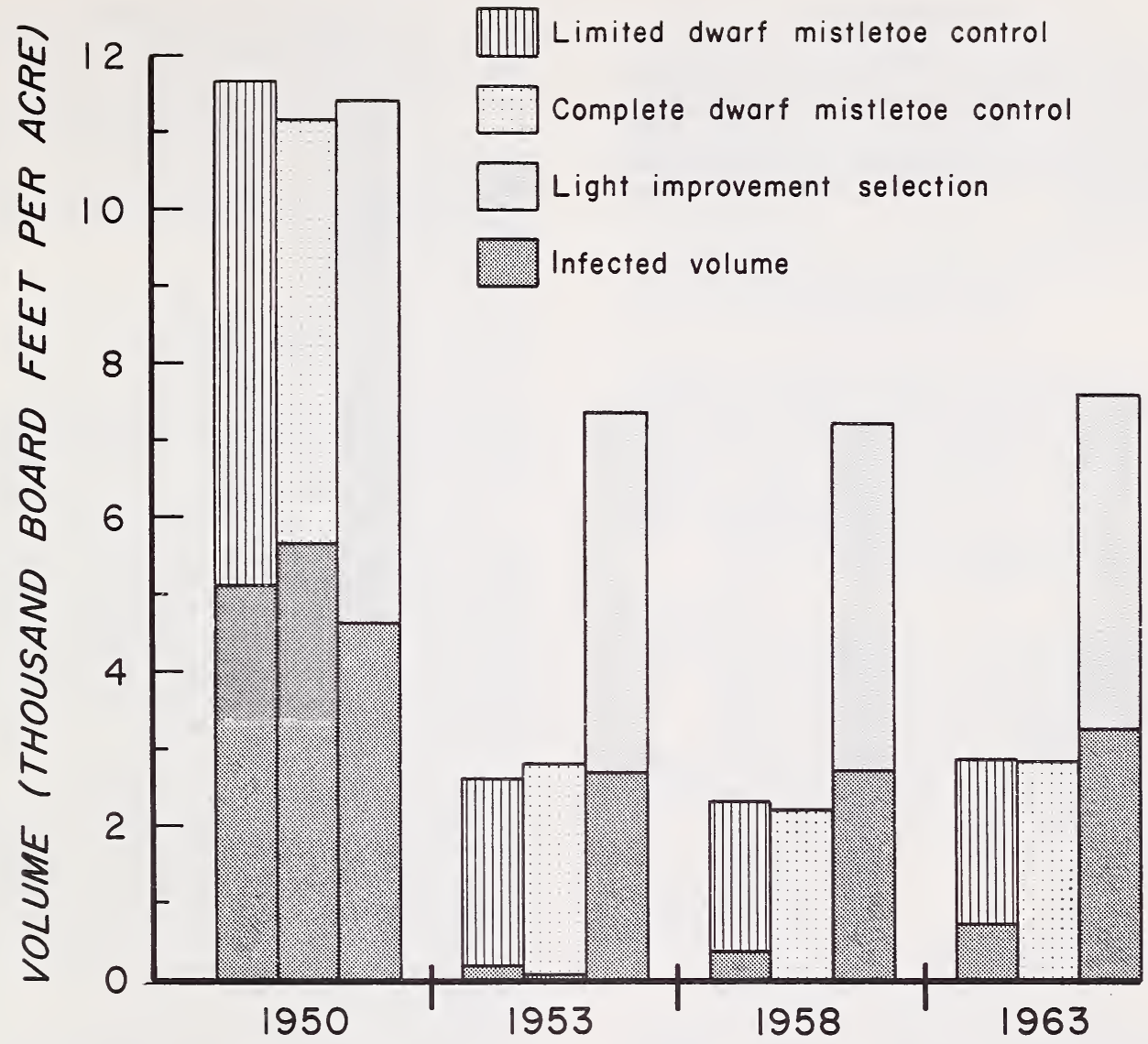

Figure 5.--Effect of three intensities of harvest cutting and stand improvement on infected and total volume of ponderosa pine sawtimber.

Figure 6.--Part of a group of ponderosa pines that blew down on a limited control plot in November 1957.

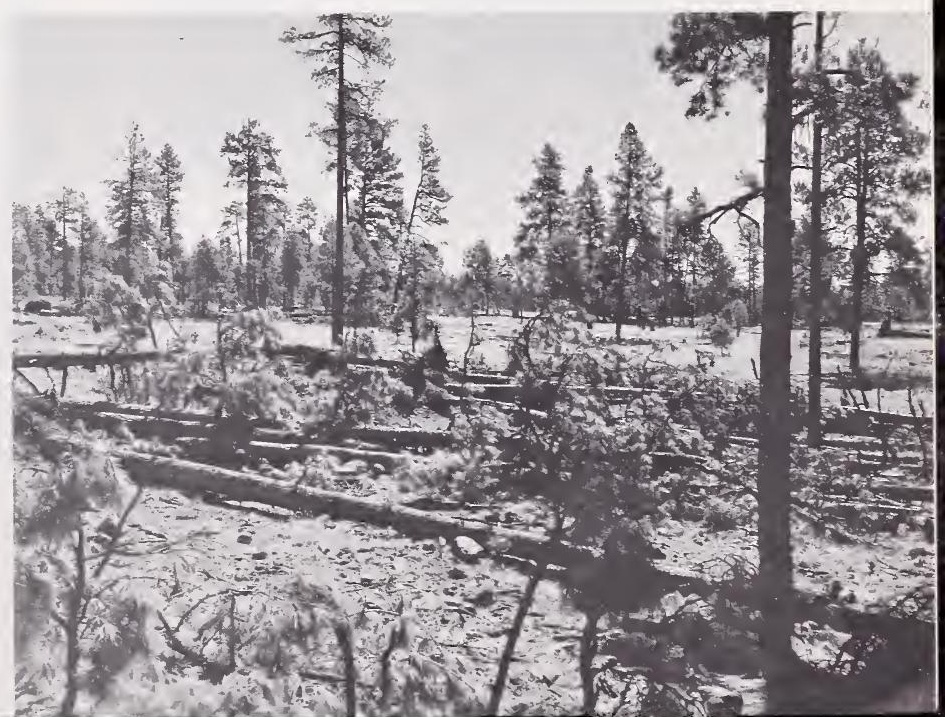




\section{Reforestation}

Approximately one-third of the study area (74 acres) is now nonstocked, with most of this acreage in the LC and CC plots. Site preparation, possibly followed by planting, will be necessary to get these acres back into production.

\section{Costs and Returns}

About twice as much time was expended to establish and treat the LC and CC areas as for LIS, with slightly more time required for CC than LC:

$$
\frac{\text { LC }}{\text { (Man-hours per acre) }}
$$

Study establishment

(1951-53):

\begin{tabular}{|c|c|c|c|}
\hline $\begin{array}{l}\text { Marking for } \\
\text { harvest cut }\end{array}$ & 1.20 & 1.22 & 0.22 \\
\hline $\begin{array}{l}\text { Timber sale } \\
\text { administration }\end{array}$ & 1.72 & 1.56 & .72 \\
\hline $\begin{array}{l}\text { Timber stand } \\
\text { improvement }\end{array}$ & 6.97 & 7.49 & 4.66 \\
\hline Total & 9.89 & 10.27 & 5.60 \\
\hline $\begin{array}{l}\text { irst re-treatment } \\
1958-59)\end{array}$ & 4.63 & 4.51 & 0 \\
\hline Tota 1 & 14.52 & 14.78 & 5.60 \\
\hline
\end{tabular}

The 1958-59 retreatment on LC and CC plots approximated 5 man-hours per acre, and cost $\$ 9.14$ and $\$ 8.64$, respectively. The LIS plots were not re-treated.

More than twice as much sawtimber was harvested from LC and CC areas as from LIS, with the greatest volume from the LC plots. Most pulpwood was cut from the CC plots. The per-acre harvest was:

$$
\frac{\text { Sawtimber }}{\text { (Bd.ft.) }} \quad \frac{\text { Pulpwood }}{\text { (Cords) }}
$$

$\begin{array}{lrl}\text { Limited control: } & & \\ \text { 1951-53 } & 8,990 & 2.37 \\ \text { 1958 } & 640 & 0 \\ \text { Complete control: } & & \\ \text { 1951-53 } & 8,160 & 3.36 \\ \text { 1958 } & 615 & 0 \\ \text { Light improvement } & \text { selection: } & \\ \text { 1951-53 } & 4,040 & 0 \\ 1958 & 533 & 0\end{array}$

The volume harvested in 1958 from the blowdown was slightly greater from LC and CC than from LIS plots.

The revenue per acre on the study areas was:

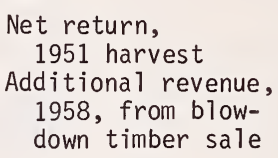

$\begin{array}{ccc}\stackrel{\text { LC }}{ } & \underline{C C} & \underline{\text { LIS }} \\ \$ 101.63 & \$ 92.24 & \$ 46.91 \\ 6.30 & 6.10 & 5.25\end{array}$

\section{Discussion}

Silvicultural control of dwarf mistletoe in heavily infected stands of ponderosa pine in the Southwest is possible. It is necessary, however, to almost clearcut the original stand.

Results were similar from LC and CC treatments, primarily because of the similarity of the overstory on the study areas. At least 75 percent of the sawtimber volume was removed for each treatment, and both treated areas were slightly more than half stocked. In both LC and $\mathrm{CC}$, all infected overstory trees were cut, for three reasons:

1. Infection spreads most rapidly from overstory trees to an understory (Gill and Hawksworth 1954), while the spread through even-aged stands is comparatively slow.

2. The parasite is stimulated in the residual trees of cutover stands, and in a short time reaches serious proportions (Hawksworth 1961).

3. Vigorous trees are more susceptible to infection than trees of poor vigor (Hawksworth 1961).

Many of the ponderosa pine stands in the Southwest are two storied-they have an overstory of mature and overmature trees, with an understory of poles and saplings under 50 years of age. In stands such as these, the spread of dwarf mistletoe is intensified by partial cutting, in heavily infected stands it would seem logical to clearcut the overstory, which would eliminate the major source of infection, as well as eliminate the windthrow problem. Infection in the understory is usually spottyin groups or patches. Heavily infected pole stands could be clearcut for pulpwood. In lightly infected pole and sapling stands, infected trees can be pruned or thinned. The opening left by clearcutting the overstory can be planted. 


\section{Summary and Conclusions}

In 1950 , a study was begun on the Fort Valley Experimental Forest, Arizona, to test silvicultural control of dwarf mistletoe on southwestern ponderosa pine. Three degrees of control were replicated three times on nine 25-acre treatment plots. The three treatments were:

1. Limited control (LC) by harvest cutting and stand improvement, to reduce the-infection to a level unimportant to timberproduction;

2. Complete control (CC), to reduce the infection to a level as near zero as possible; and

3. Light improvement selection (LIS) cutting.

Under both LC and CC treatments, over 75 percent of the sawtimber volume wasr emoved. Infected stocking was reduced from 46 to 4 percent under LC and from 52 to 3 percent under CC. LIS cutting removed 35 percent of the sawtimber volume, but did not reduce the proportion of infected stocking. A windstorm in 1957 removed an additional 250,000 board feet from the study area. Before re-treatment in 1958, the rules for cutting the LC plots were modified in an attempt to widen the difference between LC and CC. In 1963, stocking was 17 percent higher on LC plots than on CC plots.

Stocking under all three treatments increased between 1959 and 1963, with the greatest gains on LC plots. The sawtimber volume was about the same in 1963 as after establishment in 1951, but infected volume under LC has tripled since 1953, and is now almost 25 percent.

The following conclusions may be drawn from this study:

1. Dwarf mistletoe can be controlled silviculturally in heavily infected stands of ponderosa pine in the Southwest.

2. Silvicultural control of heavy infections of dwarf mistletoe involves almost complete destruction of the original stand. Clearcutting the overstory seems indicated.

3. Limited dwarf mistletoe control as used in this study seems to be impractical. The infected sawtimber volume under this treatment tripled in 10 years, and amounts to almost one-fourth of the total.

4. Heavily opened stands are highly susceptible to windthrow.
The cost of LC and CC treatments was more than twice the cost for LIS, but the returns were correspondingly higher. Since CC and LC cost approximately the same, it seems logical to eliminate the infection entirely by clearcutting and beginning a new stand. This would eliminate the necessity of re-treatments in the future.

Dwarf mistletoe control appears to be a sound management objective in heavilyinfected stands if the control is complete.

\section{Literature Cited}

Andrews, Stuart R., and Daniels, John P.

1960. A survey of dwarfmistletoes in Arizona and New Mexico.* U. S. Forest Serv., Rocky Mountain Forest and Range Exp. Sta. Sta. Pap. 49, 17 pp., illus.

Gill, Lake S.

1954. Dwarfmistletoe of ponderosa pine in the Southwest.* U. S. Forest Serv., Rocky Mountain Forest and Range Exp. Sta. Sta. Pap. 14, 9 pp., illus. and Hawksworth, Frank G.

1954. Dwarfmistletoe control in southwestern ponderosa pine forests under management. J. Forest. 52: 347-353, illus.

Hawksworth, Frank G.

1961. Dwarfmistletoe of ponderosa pine in the Southwest. U. S. Dep. Agr. Tech. Bull. 1246, 112 pp., illus.

Herman, F. R.

1961. Silvicultural control of dwarfmistletoe on southwestern ponderosa pine, a progress report.* U. S. Forest Serv., Rocky Mountain Forest and Range Exp. Sta. Sta. Pap. 62, 20 pp., illus.

Korstian, Clarence F., and Long, W. H.

1922. The western yellow pine mistletoe. U. S. Dep. Agr. Bull. 1112, 35 pp., illus.

U. S. Forest Service.

1958. Criteria for rating productivity: Procedures for western United States. In Timber resources for America's future. U. S. Forest Resources Rep. 14, pp. 676-704.

*Address requests for copies to the originating office. 



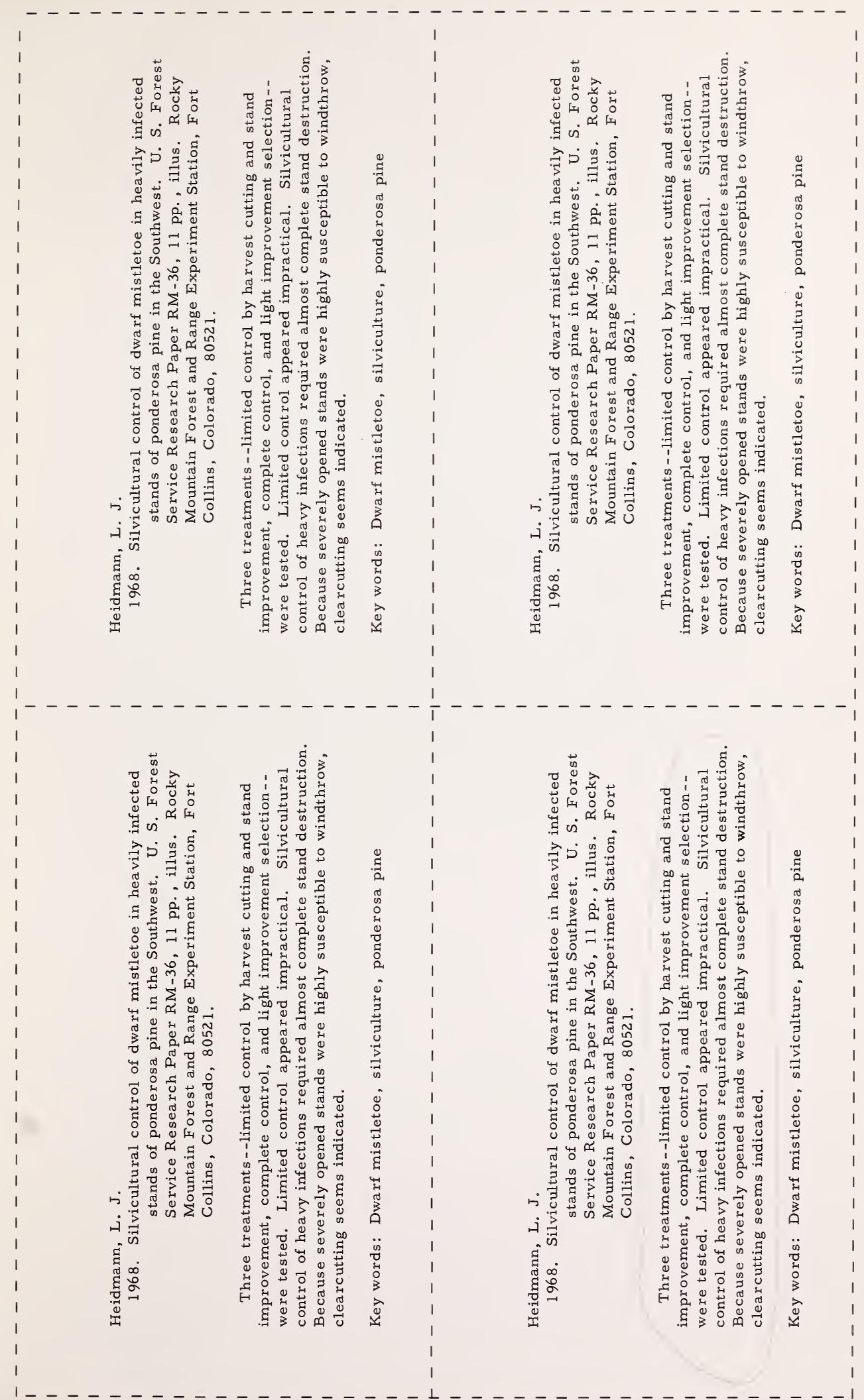




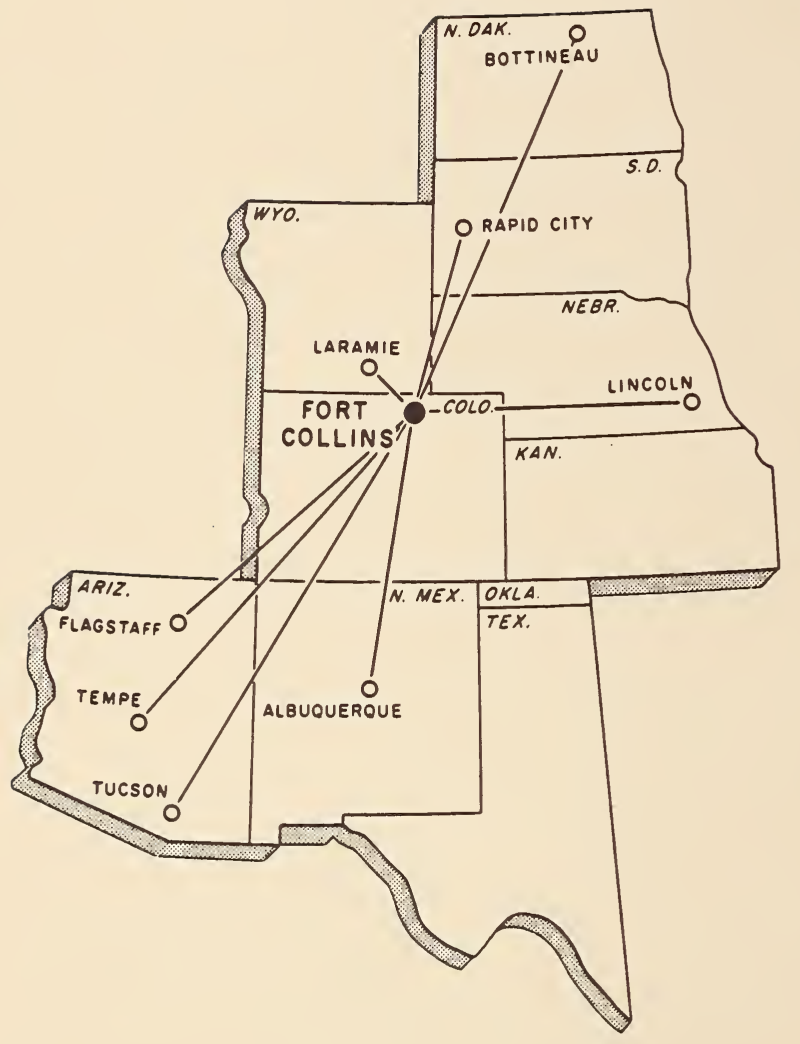

